\title{
Advancements in the Treatment of Psoriasis: Role of Biologic Agents
}

\author{
SHELDON J. RICH, RPh, PhD, and CRISTINA E. BELLO-QUINTERO, PharmD
}

\begin{abstract}
OBJECTIVE: To evaluate the role of biologic agents as antipsoriatic therapy.

SUMMARY: Mild psoriasis can generally be managed with topical therapy. Moderate-to-severe psoriasis has traditionally been treated with systemic therapies such as cyclosporine, methotrexate, retinoids, and phototherapy (ultraviolet $B$, psoralen plus ultraviolet $A$ ). The treatments for moderate-to-severe psoriasis often do not meet patient and physician expectations because of significant side effects (e.g., organ toxicity, skin cancer), lack of durable efficacy, and inconvenient administration schedules (e.g., daily dosing, multiple weekly exposures). The recognition of psoriasis as a T-cell-mediated disease has led to the development of biologic agents that more specifically target key steps in the pathologic process. A review of the literature was conducted to identify randomized controlled trials that have been published on the efficacy, safety, and quality-of-life effects of both approved and investigational biologics for the treatment of psoriasis. The first 2 biologic agents for the treatment of moderate-to-severe chronic plaque psoriasis were approved by the U.S. Food and Drug Administration (FDA) in 2003, alefacept in January and efalizumab in October. Both agents have demonstrated favorable safety profiles in clinical trials and significant benefits on patient quality of life. Head-to-head trials are lacking, but in placebocontrolled trials, similar percentages of patients appear to respond to each of these 2 drugs. An advantage of alefacept is that it has been shown in clinical trials to provide durable off-treatment efficacy ( 7 months). Efalizumab has a relatively quick onset of antipsoriatic effect, but it needs to be administered once weekly continuously to maintain symptom control. Etanercept (approved by the FDA for treating moderate-to-severe plaque psoriasis in May 2004) and infliximab (not FDA-approved for psoriasis treatment) have also shown promise in randomized controlled trials, although less data are available on these agents. Case reports and pilot studies suggest that other biologics under investigation may also prove useful for the treatment of psoriasis. Patient populations that may particularly benefit from biologic therapy are discussed.
\end{abstract}

CONCLUSION: Biologic agents appear to offer a safe and effective alternative to conventional systemic therapies and phototherapy for the treatment of moderateto-severe chronic plaque psoriasis. The biologics appear to be safer than traditional therapies, although long-term safety data still need to be established.

KEYWORDS: Alefacept, Efalizumab, Etanercept, Infliximab, Psoriasis

J Manag Care Pharm. 2004;10(4):318-25

Authors

SHELDON J. RICH, RPh, PhD, is president, SJR Associates, LLC, West Bloomfield, Michigan; clinical assistant professor, University of Michigan, Ann Arbor; and adjunct assistant professor, Wayne State University, Detroit, Michigan. CRISTINA E. BELLO-QUINTERO, PharmD, is a clinical pharmacist, North Florida Regional Medical Center, Gainesville, Florida. (At the time of this study, Bello-Quintero was an assistant professor, pharmacy practice, Nova Southeastern University College of Pharmacy, Fort Lauderdale, Florida.)

AUTHOR CORRESPONDENCE: Sheldon J. Rich, RPh, PhD, President, SJR Associates, LLC, 4223 Fieldbrook Rd.,West Bloomfield, MI 48323-3207.

Tel: (248) 932-8500; Fax: (248) 932-2972; E-mail: SJRAssociates@aol.com

Copyright $\odot$ 2004, Academy of Managed Care Pharmacy. All rights reserved.
$\mathrm{P}$ soriasis is a lifelong immune-mediated disease affecting approximately $1.5 \%$ of the world's population and is characterized by periods of exacerbations and remission. ${ }^{1}$ Of the 3 to 5 million people in the United States who are affected by psoriasis, approximately $20 \%$ to $25 \%$ have extensive disease requiring aggressive therapy.,

Although rarely life-threatening, psoriasis is associated with significant morbidity and is considered by many to be an emotionally crippling disease. ${ }^{2}$ The impact of psoriasis on physical and emotional functioning is as great as that of many other serious medical conditions, such as cancer, heart disease, and Crohn's disease. ${ }^{4}$ As many as $25 \%$ of patients with psoriasis have considered suicide because of their disease. ${ }^{5}$

In a recent survey of patients with severe psoriasis, $79 \%$ reported that psoriasis had a negative impact on their lives, $40 \%$ felt frustration with current treatments, and 32\% did not perceive their treatment to be sufficiently aggressive. ${ }^{6}$ Biologic agents represent new agents for patients who suffer from moderate-to-severe psoriasis. The primary objective of this article is to evaluate the efficacy data and potential role of biologic agents for the treatment of moderate-to-severe chronic plaque psoriasis. Conventional therapies will be briefly reviewed.

\section{Definition of the Disease}

Recent scientific advances have highlighted the role of the immune system in psoriasis. ${ }^{7.8}$ Activation of memory T-cells is a key immune system trigger. Activated T-cells release cytokines, which signal accelerated epidermal cell turnover and the keratinocyte and vascular changes seen in psoriasis. These alterations result in the characteristic psoriatic phenotype of red, thick, and scaly lesions. ${ }^{9}$

\section{Goals of Therapy}

The ideal therapy for psoriasis is an efficacious, long-lasting agent devoid of acute or long-term adverse effects, with minimal monitoring requirements, and a dosing regimen that eases compliance. One of the goals of therapy is to reduce or clear plaques and induce remission. ${ }^{10}$ Remission periods may help to reduce treatment costs while maintaining improvements in patients' quality of life. ${ }^{11,12}$ While there is no cure for psoriasis, certain topical regimens have been shown to produce complete clearing in patients with less-severe disease, ${ }^{13}$ and at least one biologic agent has been shown to induce periods of remission in patients with moderate-to-severe psoriasis. ${ }^{14,15}$

\section{Types and Severity of Psoriasis}

Several specific subtypes of psoriasis are recognized. The most common type of psoriasis, affecting more than $90 \%$ of patients, 


\begin{tabular}{|c|c|c|c|c|}
\hline Therapy & Dosing Requirements & Efficacy & Primary Tolerability Concerns & $\begin{array}{c}\text { Key Dosing Limitations/ } \\
\text { Monitoring Due to Side Effects }\end{array}$ \\
\hline Acitretin & Daily & $\begin{array}{l}\text { Suppressive therapy } \\
\text { More effective in pustular and } \\
\text { erythrodermic psoriasis than } \\
\text { chronic plaque psoriasis } \\
\text { Often combined with phototherapy }\end{array}$ & Teratogenic & $\begin{array}{l}\text { 3-year washout period required } \\
\text { before pregnancy } \\
\text { Monitoring for hepatotoxicity } \\
\text { and hypertriglyceridemia required }\end{array}$ \\
\hline Cyclosporine & Daily & $\begin{array}{l}\text { Suppressive therapy } \\
\text { Effective in all forms of psoriasis }\end{array}$ & $\begin{array}{l}\text { Renal toxicity with long-term use } \\
\text { Hypertension } \\
\text { Increased risk of malignancies } \\
\text { and infections due to } \\
\text { generalized immunosuppression }\end{array}$ & $\begin{array}{l}\text { Not approved for continuous } \\
\text { use }>1 \text { year }\end{array}$ \\
\hline Methotrexate & Weekly & $\begin{array}{l}\text { Suppressive therapy } \\
\text { Effective in all forms of psoriasis } \\
\text { Particularly effective in patients } \\
\text { with psoriatic arthritis }\end{array}$ & $\begin{array}{l}\text { Bone marrow toxicity with } \\
\text { short-term use } \\
\text { Hepatic toxicity with } \\
\text { long-term use } \\
\text { Increased risk of malignancies } \\
\text { and infections due to generalized } \\
\text { immunosuppression }\end{array}$ & $\begin{array}{l}\text { Liver biopsy required at } \\
\text { cumulative doses }>1.5 \mathrm{~g}\end{array}$ \\
\hline PUVA & $\begin{array}{l}\text { Multiple weekly } \\
\text { treatments }\end{array}$ & $\begin{array}{l}\text { Remittive therapy } \\
\text { Often combined with topical } \\
\text { and other systemic agents }\end{array}$ & $\begin{array}{l}\text { Skin cancer (squamous cell } \\
\text { carcinoma and possibly } \\
\text { malignant melanoma) }\end{array}$ & $\begin{array}{l}\text { Not recommended in patients } \\
\text { with history of skin cancer }\end{array}$ \\
\hline UVB & $\begin{array}{l}\text { Multiple weekly } \\
\text { treatments }\end{array}$ & $\begin{array}{l}\text { Suppressive therapy } \\
\text { Rapid onset of action } \\
\text { Narrowband may be more } \\
\text { effective than broadband UVB } \\
\text { Often combined with topical } \\
\text { and other systemic agents }\end{array}$ & $\begin{array}{l}\text { Erythema, vesiculation, } \\
\text { premature skin aging }\end{array}$ & - \\
\hline
\end{tabular}

is chronic plaque psoriasis or psoriasis vulgaris. ${ }^{2}$ Other types of psoriasis include guttate, erythrodermic, and pustular psoriasis. ${ }^{1,2}$ Psoriatic arthritis is seen in approximately $30 \%$ of patients with psoriasis and, if left untreated, can cause significant joint damage. ${ }^{2,6}$ Individuals with psoriatic arthritis generally experience stiffness, pain, swelling, and tenderness of the affected joints, typically the wrists, knees, ankles, neck, and lower back.

In developing a treatment plan, it is helpful to separate patients with mild local psoriasis from patients with moderateto-severe disease. Disease severity is often classified based on body surface area involvement (i.e., $\leq 2 \%$, mild; $3 \%$ to $10 \%$, moderate; $>10 \%$, severe) ${ }^{16}$ Patients with mild-to-moderate psoriasis can generally manage their disease effectively with topical therapies, including emollients, keratolytics, anthralin, coal tar, corticosteroids, vitamin D analogues (calcipotriene [Dovonex]), and topical retinoids (tazarotene [Tazorac]). Systemic therapies are not typically used because the impact of the disease on these patients does not justify the potential risks of more intensive therapy. Patients with moderate-to-severe disease or who are otherwise disabled by their psoriasis (for example, painful involvement of the soles of the feet, palms, face, or genitals) are impacted so greatly that the risks of systemic therapies may be justified.

\section{Treatment of Moderate-to-Severe Psoriasis}

Table 1 summarizes some of the key points of conventional therapies used for the treatment of moderate-to-severe psoriasis. Traditional psoriasis treatments have been the subject of numerous reviews. ${ }^{13,17-21}$ No therapy in any class offers complete healing of psoriasis for all patients. However, the conventional therapies have demonstrated varying degrees of efficacy, with some patients experiencing satisfactory symptom relief. A major 
limitation with these treatments is that most have serious side effects that limit their use. Only psoralen plus ultraviolet A (PUVA) is considered a remittive therapy (i.e., able to induce long-lasting improvements in the symptoms of psoriasis after treatment discontinuation). ${ }^{21}$ In contrast, the symptoms of psoriasis recur shortly after withdrawal of other conventional therapies. ${ }^{21}$ These latter treatments are commonly referred to as suppressive therapies. Some of the issues that may be taken into consideration when evaluating traditional therapies are the dosing regimens, drug interactions, and potential for organ toxicity (Table 1). Initial data indicate that biologic agents for psoriasis avoid these issues and, although data are limited, may provide an overall more effective treatment for patients who have moderate-to-severe disease.

An increased understanding of the role of the immune system in psoriasis has spurred the development of biologic agents for the treatment of chronic plaque psoriasis. Biologics provide a specific, targeted regulation of the cells in the immune system that are implicated in psoriasis as compared with some of the traditional, nonspecific immunosuppressive therapies (e.g., cyclosporine, methotrexate). However, monitoring for infections is prudent for the biologics since all of these agents have immunomodulatory activity. To date, biologics have not been associated with organ toxicity. Furthermore, biologics have limited problematic drug interactions since they are not metabolized through the cytochrome P450 system.

The following sections and Table 2 review the results of randomized controlled clinical trials on each of the biologic agents being studied to treat psoriasis. Of these agents, alefacept (Amevive), efalizumab (Raptiva) and, most recently, etanercept (Enbrel) have gained U.S. Food and Drug Administration (FDA) approval for this indication.

The Psoriasis Area Severity Index (PASI) is the standard for evaluating the efficacy of psoriasis treatments in clinical trials. To be considered efficacious, a new treatment must result in significantly more patients achieving a $\geq 75 \%$ reduction from baseline PASI (PASI 75) compared with placebo. However, it has been shown that substantial improvements in quality of life and visible clearing of lesions can be achieved when PASI is reduced by $50 \%$ (PASI 50). ${ }^{11,12,14,22}$ The results of a recent study of methotrexate, which is widely viewed as one of the most effective therapies for psoriasis, lends support to the difficulty in achieving PASI 75. In 25 patients with moderate-to-severe psoriasis, Callis and colleagues ${ }^{23}$ reported that 24 weeks of aggressive therapy with methotrexate resulted in a PASI 75 for only about one quarter of patients. PASI 50 was achieved by approximately two thirds of patients. For these reasons, the following sections describe PASI 50 results, whenever available.

\section{Alefacept}

Alefacept (Amevive) is a fully humanized recombinant fusion protein that modifies the inflammatory process in psoriasis. ${ }^{24,25}$
It selectively inhibits activation of memory T-cells and produces apoptosis of this T-cell subset. The FDA approved alefacept in January 2003 for the treatment of adult patients with moderateto-severe chronic plaque psoriasis who are candidates for systemic therapy or phototherapy.

Alefacept is administered once-weekly at a dose of $15 \mathrm{mg}$ via intramuscular (IM) injection. ${ }^{25}$ Circulating $\mathrm{CD}^{+}{ }^{+} \mathrm{T}$-cell counts should be monitored before initiating alefacept therapy and weekly during the 12-week treatment period. Alefacept should not be initiated in patients with a $\mathrm{CD}^{+}{ }^{+} \mathrm{T}$-cell count below normal and, if $\mathrm{CD}^{+}{ }^{+} \mathrm{T}$-cell counts drop $<250$ cells $/ \mu \mathrm{L}$, it is recommended that treatment be withheld for the subsequent week. Retreatment courses of alefacept may be initiated provided that $\mathrm{CD}^{+}{ }^{+} \mathrm{T}$-cell counts are normal and $\geq 12$ weeks have passed since the last alefacept dose of the previous course. Monitoring of $\mathrm{CD}^{+} \mathrm{T}$-cell levels is not required during the off-treatment phase.

Two randomized, double-blind, placebo-controlled phase III trials have been conducted in more than 1,000 patients with moderate-to-severe chronic plaque psoriasis. ${ }^{14,15,22}$ During the first course of treatment (i.e., 12 weeks of treatment followed by 12 weeks of observation), $56 \%$ of patients treated with alefacept $7.5 \mathrm{mg}$ intravenous (IV) and 57\% treated with alefacept $15 \mathrm{mg}$ IM achieved a PASI 50 at any time during treatment or followup (overall response rate) $(P<0.001$ versus placebo in both studies). ${ }^{14,22}$ Two courses of alefacept provided further benefit, with $71 \%$ and $69 \%$ of patients achieving a PASI 50 in the IV and IM studies, respectively. ${ }^{14,15}$ Patients who achieved a PASI 75 response during or after a single course of alefacept maintained a PASI 50 response for a median duration of 216 days $(7.5 \mathrm{mg}$ IV) or 209 days (15 mg IM). ${ }^{14,15}$

Both doses of alefacept (7.5 mg IV and $15 \mathrm{mg}$ IM) reduced circulating $\mathrm{CD}^{+}$and $\mathrm{CD} 8^{+}$T-cell counts, with selective effects on memory T-cells and sparing of naïve T-cells. ${ }^{26,27}$ The greater the magnitude of reduction in $\mathrm{CD}^{+}$and $\mathrm{CD}^{+}$memory T-cell counts, the greater the clinical response and the duration of offtreatment response. Alefacept had negligible effects on $\mathrm{CD}_{19}{ }^{+} \mathrm{B}$ cells and $\mathrm{CD} 16^{+} / \mathrm{CD} 56^{+}$natural killer cells. No evidence of a cumulative effect of alefacept on lymphocyte count or lymphocyte subset counts was observed when alefacept was administered over multiple courses.

In both phase III trials, 1 or 2 courses of alefacept were similarly well tolerated with no evidence for an increased risk of infections or malignancies and no association between these events and circulating CD4 ${ }^{+}$T-cell counts. ${ }^{14,15,22}$ The majority of infections were common colds. No opportunistic infections were reported. Discontinuation rates because of adverse events were low and similar in the alefacept and placebo groups ( $\leq 2 \%$ across all treatment groups). Pruritus was reported by a higher percentage of patients in the alefacept 15-mg group (18\%) than in the placebo group (10\%) during 1 course of IM therapy. ${ }^{22}$ Most of these events were single episodes. Injection site reactions were mild and did not lead to discontinuation of therapy 


\section{TABLE 2 Summary of Results of Randomized, Controlled Clinical Trials of} Biologic Agents for the Treatment of Moderate-to-Severe Psoriasis

\begin{tabular}{|c|c|c|c|}
\hline Biologic & Efficacy & Safety & Quality of Life \\
\hline \multirow[t]{8}{*}{ Alefacept ${ }^{11,12,14,15,22,25}$} & \multirow{2}{*}{$\begin{array}{l}\text { PASI } 50 \text { over } 1 \text { course ( } 12 \text { weeks of treatment } \\
\text { followed by } 12 \text { weeks of observation) }\end{array}$} & No increased risk of infections or malignancies & \multirow{8}{*}{$\begin{array}{l}\text { Significant improvement in DLQI, } \\
\text { DQOLS, and SF-36 with } 15 \mathrm{mg} \\
\mathrm{IM} \text { and } 7.5 \mathrm{mg} \mathrm{IV} \mathrm{IV}^{11,12}\end{array}$} \\
\hline & & \multirow{2}{*}{$\begin{array}{l}\text { Incidence of serious infections: } 0.9 \% \text { alefacept, } \\
0.2 \% \text { placebo }^{25}\end{array}$} & \\
\hline & \multirow{2}{*}{$\begin{array}{l}15 \mathrm{mg} \text { IM once weekly: } 57 \% * \text { (vs. } 35 \% \text { PBO) })^{22} \\
* 7.5 \mathrm{mg} \text { IV once weekly: } 56 \% *(\text { vs. } 24 \% \mathrm{PBO})^{14}\end{array}$} & & \\
\hline & & No opportunistic infections & \\
\hline & \multirow{3}{*}{$\begin{array}{l}\text { PASI } 50 \text { over } 2 \text { courses } \\
15 \text { mg IM once weekly: } 69 \%^{15} \text { (no patient } \\
\text { received placebo for } 2 \text { courses) } \\
* 7.5 \mathrm{mg} \text { IV once weekly } 71 \%^{14} \text { (no patient } \\
\text { received placebo for } 2 \text { courses) }\end{array}$} & \multirow{2}{*}{$\begin{array}{l}\text { Incidence of malignancies: } 1.3 \% \text { alefacept, } 0.5 \% \\
\text { placebo (majority were nonmelanoma skin } \\
\text { cancers) })^{25}\end{array}$} & \\
\hline & & & \\
\hline & & No disease rebound upon discontinuation & \\
\hline & $\begin{array}{l}\text { Duration of off-treatment response: } \sim 7 \text { months } \\
\text { with both doses }\end{array}$ & $\begin{array}{l}\text { Mild injection-site reactions with IM doses (16\% } \\
\text { alefacept, } 8 \% \text { placebo })^{25}\end{array}$ & \\
\hline \multirow[t]{8}{*}{ Efalizumab ${ }^{32-34}$} & \multirow{8}{*}{$\begin{array}{l}\text { PASI } 50 \\
1 \mathrm{mg} / \mathrm{kg} \text { once weekly SC (4 trials): } \\
52 \% \dagger(\text { vs. } 16 \% \mathrm{PBO})^{34} \\
52 \% \dagger(\text { vs. } 14 \% \mathrm{PBO})^{32} \\
59 \% \dagger(\text { vs. } 14 \% \mathrm{PBO})^{33} \\
61 \% \dagger(\text { vs. } 15 \% \mathrm{PBO})^{32} \\
\text { Requires continuous therapy for benefit }\end{array}$} & No increased risk of infections or malignancies & \multirow{8}{*}{$\begin{array}{l}\text { Significant improvement in DLQI } \\
\text { Itching Visual Analog Scale, and } \\
\text { Psoriasis Symptom Assessment } \\
\text { frequency and severity subscales }\end{array}$} \\
\hline & & Incidence of serious infections: $0.4 \%$ efalizumab, & \\
\hline & & $0.1 \%$ placebo $^{32}$ & \\
\hline & & No opportunistic infections & \\
\hline & & \multirow{2}{*}{$\begin{array}{l}\text { Incidence of malignancies: } 1.8 \text { per } 100 \text { patient-years } \\
\text { for efalizumab, } 1.6 \text { per } 100 \text { patient-years for placebo } \\
\text { (majority were nonmelanoma skin cancers) }{ }^{32}\end{array}$} & \\
\hline & & & \\
\hline & & $\begin{array}{l}\text { First-dose reaction consisting of headache, chills, } \\
\text { fever, nausea, vomiting, and myalgia is relatively } \\
\text { common ( } 29 \% \text { after first dose of } 1 \mathrm{mg} / \mathrm{kg} \text {; condi- } \\
\text { tioning dose reduces the incidence/severity) }\end{array}$ & \\
\hline & & $\begin{array}{l}\text { Disease rebound }(\sim 5 \%) \text { and thrombocytopenia } \\
(0.3 \%) \text { have been reported }{ }^{32}\end{array}$ & \\
\hline \multirow[t]{8}{*}{ Etanercept $^{35-39}$} & \multirow{2}{*}{$\begin{array}{l}\text { PASI } 50 \\
25 \mathrm{mg} \text { once weekly SC } \\
41 \% \dagger \text { at week } 12 \text { (vs. } 14 \% \text { PBO), } 58 \% \text { at week } 24^{39}\end{array}$} & $\begin{array}{l}\text { No opportunistic infections reported in psoriasis } \\
\text { patients }\end{array}$ & \multirow[t]{8}{*}{$\begin{array}{l}\text { Significant improvement in } \\
\text { DLQI }^{38,39}\end{array}$} \\
\hline & & \multirow{4}{*}{$\begin{array}{l}\text { Mild injection site reactions ( } 9 \%-20 \% \text { etanercept, } \\
0 \%-7 \% \text { placebo), upper respiratory tract infections } \\
\text { (5\%-35\% etanercept, } 11 \%-20 \% \text { placebo), and } \\
\text { sinusitis (up to } 14 \% \text { etanercept, up to } 4 \% \text { placebo) } \\
\text { were common in psoriasis patients }{ }^{38,39}\end{array}$} & \\
\hline & \multirow{4}{*}{$\begin{array}{l}25 \mathrm{mg} \text { twice weekly SC ( } 3 \text { trials) } \\
58 \% \dagger \text { at week } 12 \text { (vs. } 14 \% \text { PBO), } 70 \% \text { at week } 24^{39} \\
70 \% \dagger \text { at week } 12 \text { (vs. } 11 \% \text { PBO), } 77 \% * \text { at week } 24 \\
\text { (vs. } 13 \% \text { PBO) } \\
40 \% \text { at week } 12 \text { (vs. } 20 \% \text { PBO) })^{37}\end{array}$} & & \\
\hline & & & \\
\hline & & & \\
\hline & & \multirow{2}{*}{$\begin{array}{l}\text { RA patients have experienced increased risk of TB } \\
\text { ( } 38 \text { cases reported in } 150,000 \text { treated patients })^{36}\end{array}$} & \\
\hline & \multirow{2}{*}{$\begin{array}{l}50 \mathrm{mg} \text { twice weekly SC } \\
74 \% \dagger \text { at week } 12 \text { (vs. 14\% PBO), } 77 \% \text { at week } 24^{39}\end{array}$} & & \\
\hline & & Contraindicated in patients with sepsis & \\
\hline \multirow[t]{7}{*}{ Infliximab $36,40,41$} & \multirow{7}{*}{$\begin{array}{l}\text { PASI } 50 \text { not reported } \\
\text { PASI } 75 \\
5 \mathrm{mg} / \mathrm{kg} \text { ( } 3 \text { IV infusions) } \\
82 \% \ddagger \text { at week } 10 \text { (vs. 18\% PBO) })^{41} \\
10 \mathrm{mg} / \mathrm{kg} \text { ( } 3 \mathrm{IV} \text { infusions) } \\
73 \% \S \text { at week } 10 \text { (vs. } 18 \% \mathrm{PBO})^{41}\end{array}$} & \multirow{3}{*}{$\begin{array}{l}\text { Headache was common in psoriasis patients ( } 9 \% \\
\text { with } 5 \mathrm{mg} / \mathrm{kg}, 64 \% \text { with } 10 \mathrm{mg} / \mathrm{kg}, 18 \% \text { with } \\
\text { placebo) }\end{array}$} & \multirow[t]{7}{*}{ Not reported } \\
\hline & & & \\
\hline & & & \\
\hline & & \multirow{2}{*}{$\begin{array}{l}\text { RA patients have experienced increased risk of TB } \\
\text { (172 cases reported in } 200,000 \text { treated patients })^{36}\end{array}$} & \\
\hline & & & \\
\hline & & $\begin{array}{l}\text { Tuberculin skin test required before initiating } \\
\text { infliximab }\end{array}$ & \\
\hline & & $\begin{array}{l}\text { Contraindicated ( }>5 \mathrm{mg} / \mathrm{kg} \text { ) in patients with heart } \\
\text { failure }\end{array}$ & \\
\hline $\begin{array}{l}\text { PASI }=\text { Psoriasis Ared } \\
\text { DQOLS = Dermatolo } \\
* \text { IV formulation no } \\
+P<0.001 \text { vs. placel }\end{array}$ & $\begin{array}{l}\text { Severity Index; } P B O=\text { placebo; IM = intramuscular; } I V= \\
\text { gy Quality of Life Scales; SF-36 = Short Form-36; RA =r } \\
\text { onger marketed. } \quad \ddagger P<0.01 \text { vs. placebo. } \\
\text { o. } \quad \& P<0.05 \text { vs. placebo. }\end{array}$ & $\begin{array}{l}\text { travenous; } S C=\text { subcutaneous; DLQI = Dermatology I } \\
\text { matoid arthritis; } T B=\text { tuberculosis. }\end{array}$ & ife Quality Index; \\
\hline
\end{tabular}


in any patient. Antialefacept antibodies developed in few patients ( $\leq 3 \%$ in 7.5 -mg IV and $15-\mathrm{mg}$ IM groups) and, in all cases, titers were low and not associated with hypersensitivity reactions. No cases of disease rebound were observed. In a separate study, immune function was maintained during alefacept treatment as assessed by immune responses to recall (tetanus) and novel (bacteriophage phi-X174) antigens. ${ }^{28}$

Finlay and colleagues reported the effects of alefacept on patient quality of life based on the phase III trial of IM alefacept. ${ }^{11}$ Alefacept $15 \mathrm{mg}$ significantly improved all 3 qualityof-life measures compared with placebo, including the Dermatology Life Quality Index (DLQI), Dermatology Quality of Life Scales (DQOLS), and Short Form-36 (all $P<0.05$ at 2 weeks after last dose). Patients did not need to achieve complete clearing of lesions or a PASI 75 to experience significant enhancement in quality of life. PASI 50 was a clinically meaningful predictor of the quality-of-life benefit of alefacept. Similar findings were observed with alefacept $7.5 \mathrm{mg} \mathrm{IV.}{ }^{12}$

The findings of a phase II trial and an open-label retreatment trial were consistent with the phase III results. ${ }^{8,29,30}$

\section{Efalizumab}

Efalizumab (Raptiva) is a humanized monoclonal antibody that prevents T-cells from becoming activated, adhering to endothelial cells, and moving from the circulatory system to the skin. ${ }^{31,32}$ In October 2003, efalizumab became the second biologic to be approved by the FDA for the treatment of psoriasis. Like alefacept, efalizumab is indicated for the treatment of adult patients with moderate-to-severe chronic plaque psoriasis who are candidates for systemic therapy or phototherapy.

Patients can self-inject efalizumab after proper training in the preparation and injection technique..$^{32}$ Efalizumab is administered as a single $0.7 \mathrm{mg} / \mathrm{kg}$ subcutaneous (SC) injection (conditioning dose) followed by once-weekly doses of $1 \mathrm{mg} / \mathrm{kg} \mathrm{SC}$. The maximum single dose should not exceed $200 \mathrm{mg}$. The prescribing information for efalizumab states that a conditioning dose reduces the incidence and severity of a first-dose reaction (headache, chills, fever, nausea, vomiting, and myalgia). The incidence of this reaction without a conditioning dose was 29\% in the efalizumab $1 \mathrm{mg} / \mathrm{kg}$ group and $15 \%$ in the placebo group after the first dose, and $4 \%$ and $3 \%$, respectively, after the third dose. Less than $1 \%$ of patients discontinued efalizumab because of the reaction.

The results of 2 randomized, double-blind, placebocontrolled phase III trials in more than 1,100 patients with moderate-to-severe plaque psoriasis have been published. ${ }^{33,34} \mathrm{In}$ these studies, $52 \%$ to $59 \%$ of patients achieved a PASI 50 after 12 once-weekly injections of efalizumab $1 \mathrm{mg} / \mathrm{kg}$ SC $(P<0.001$ versus placebo). Similar results in favor of efalizumab $1 \mathrm{mg} / \mathrm{kg}$ SC over placebo were reported for 2 additional pivotal studies, which are included in the product labeling but as of yet are unpublished (Table 2). Efalizumab has a relatively rapid onset of action, with significant improvements in mean PASI scores noted as early as week 4. Efalizumab is a suppressive rather than remittive therapy, which means that it needs to be taken continuously to maintain symptom control.

Efalizumab was generally well tolerated in clinical trials. ${ }^{32-34}$ No evidence for an increased risk of infections or malignancies was observed, and no opportunistic infections were reported. Few patients discontinued because of adverse events in the published trials (3\% to $4 \%$ efalizumab $1 \mathrm{mg} / \mathrm{kg}, 1 \%$ to $2 \%$ placebo).

Efalizumab may cause thrombocytopenia; therefore, it is recommended to measure platelets before initiating therapy and periodically during treatment (monthly initially, less frequently thereafter). In the combined safety database from all studies, thrombocytopenia (platelet count $<52,000$ cells $/ \mu \mathrm{L}$ ) occurred in 8 of 2,762 efalizumab-treated patients and no placebo-treated patient. Efalizumab was discontinued in each case. Five of the 8 patients received a course of systemic steroids. The adverse event resolved in 7 patients ( 1 patient was lost to follow-up). Rebound disease occurred in 14 patients after stopping efalizumab therapy, and an additional 5 patients had serious worsening of psoriasis during treatment. Hospitalization and alternative psoriasis therapy was required in some cases. Approximately $6 \%$ of patients developed antibodies against efalizumab, but no safety concerns were noted. In a separate small study, a single dose of efalizumab $1 \mathrm{mg} / \mathrm{kg}$ IV administered before primary immunization with a neoantigen almost completely ablated the secondary immune response. ${ }^{32}$

In one of the phase III trials, efalizumab $1 \mathrm{mg} / \mathrm{kg}$ SC significantly improved the DLQI, Itching Visual Analog Scale, and Psoriasis Symptom Assessment frequency and severity subscales compared with placebo (all $P<0.001$ at week 12). ${ }^{33}$

\section{Etanercept}

Etanercept (Enbrel) is a recombinant human tumor necrosis factor (TNF)-receptor fusion protein that competitively inhibits the effects of endogenous TNF, an inflammatory cytokine, by interacting with cell-surface receptors. ${ }^{35}$ Etanercept is approved for the treatment of rheumatoid arthritis, juvenile rheumatoid arthritis, psoriatic arthritis, and ankylosing spondylitis. It received an FDA-approved indication for treating chronic moderate-to-severe plaque psoriasis in May 2004.

Etanercept may be associated with an increased risk of serious infections..$^{35}$ The FDA reported that 38 of the approximately 150,000 etanercept-treated patients with rheumatoid arthritis developed tuberculosis. ${ }^{36}$ However, latent tuberculosis testing is not required before initiating etanercept. ${ }^{35}$ Etanercept is contraindicated in patients with sepsis.

Three randomized, double-blind, placebo-controlled trials have been published on the use of etanercept as a treatment for psoriasis. ${ }^{37-39}$ In the earliest study, 60 patients with psoriatic arthritis, 38 of whom also had psoriasis involving $\geq 3 \%$ body 
surface area, received either etanercept $25 \mathrm{mg}$ SC twice weekly or matching placebo for 12 weeks. ${ }^{37}$ In patients with psoriasis, PASI 50 was achieved at 12 weeks in about $40 \%$ and $20 \%$ of patients (estimated from bar graphs) in the etanercept and placebo groups, respectively $(P=N S)$. The safety analysis included all 60 patients. The incidences of the following adverse events were more common among etanercept-treated patients than placebo-treated patients: upper respiratory tract infections (27\% versus 13\%, respectively), mild injection site reactions ( $20 \%$ versus $3 \%$ ), and fatigue ( $13 \%$ versus $0 \%$ ). No etanercept-treated patient discontinued therapy because of an adverse event. No infection required hospitalization or IV antibiotics. This publication did not report on the development of antietanercept antibodies or the quality-of-life effects of etanercept in patients with psoriasis.

In another trial, 112 patients with moderate-to-severe chronic plaque psoriasis were randomized to receive etanercept $25 \mathrm{mg}$ SC twice weekly or matching placebo for 24 weeks. ${ }^{38}$ The percentage of etanercept-treated patients achieving a PASI 50 was $70 \%$ at week 12 and $77 \%$ at week 24 (both $P<0.001$ versus placebo). A significant reduction in mean PASI scores was observed at the first time point measured (week 2). The duration of off-treatment response was not assessed. With regard to tolerability, the incidence of discontinuations because of adverse events was lower in the etanercept group than in the placebo group (4\% versus 11\%). As compared with placebo, upper respiratory tract infections (35\% etanercept, 20\% placebo), sinusitis (14\%, 4\%), and mild injection site reactions (9\%, 0\%) were more common in the etanercept group. No cases of opportunistic infections or skin cancers were observed. Tuberculosis did not occur in this trial. Antibodies against etanercept were not assessed. Etanercept significantly improved quality of life compared with placebo, as measured by mean percentage improvement in DLQI scores, as early as the first time point evaluated (week 4) ( $P$ value not provided).

Leonardi and colleagues conducted the largest trial of etanercept, which included 652 patients with moderate-to-severe chronic plaque psoriasis. ${ }^{39}$ Patients were separated into 4 dosing regimens: etanercept SC (25 mg once weekly, $25 \mathrm{mg}$ twice weekly, or $50 \mathrm{mg}$ twice weekly) for 24 weeks or placebo SC for 12 weeks followed by etanercept $25 \mathrm{mg}$ SC twice weekly for 12 weeks. At week 12, 41\%,58\%, and 74\% of patients in the etanercept low-, medium-, and high-dose groups, respectively, achieved a PASI 50 (all $P<0.001$ versus placebo). Corresponding results at week 24 were $58 \%, 70 \%$, and $77 \%$. All doses of etanercept significantly improved mean PASI scores compared with placebo as early as week 2 . An evaluation of the duration of off-treatment response was not completed. The most common adverse events over the initial 12 weeks of the study were injection site reactions ( $11 \%$ to $17 \%$ across etanercept groups, $7 \%$ placebo). The frequency of other adverse events was similar across the treatment groups. No opportun- istic infections or cases of tuberculosis were reported. Antietanercept antibodies were detected in $2 \%$ of patients. Etanercept was associated with dose-related mean percentage improvements in DLQI scores, with significant differences over placebo evident as early as week 2 ( $P$ values not specified at this time point).

\section{Infliximab}

Infliximab (Remicade) is a chimeric monoclonal antibody that specifically inhibits TNF alpha. ${ }^{40}$ It is approved for the treatment of rheumatoid arthritis, in combination with methotrexate, and for the treatment of Crohn's disease. Infliximab is not FDA-approved for the treatment of psoriasis.

Infliximab carries a Black Box warning regarding the risk of serious infections, including tuberculosis. ${ }^{40}$ Among the approximately 200,000 patients with rheumatoid arthritis who received infliximab through 2002, the FDA reported that 172 cases of tuberculosis were identified..$^{36}$ Because of this association, patients should be evaluated for latent tuberculosis infection with a tuberculin skin test. ${ }^{40}$ Treatment of latent tuberculosis infection should be initiated before therapy with infliximab. Infliximab $(>5 \mathrm{mg} / \mathrm{kg})$ is contraindicated in patients with moderate-to-severe heart failure.

One small $(\mathrm{N}=33)$ randomized clinical trial has been published on the efficacy and safety of infliximab for the treatment of moderate-to-severe chronic plaque psoriasis (Table 2). ${ }^{41}$ Patients received infliximab $5 \mathrm{mg} / \mathrm{kg}$, infliximab $10 \mathrm{mg} / \mathrm{kg}$, or placebo by 2-hour IV infusion at weeks 0,2 , and 6 , and were then followed through week 10. Investigators and patients were blinded to treatment assignment during this time. At week 10, $82 \%$ of patients treated with the lower dose of infliximab and $73 \%$ treated with the higher dose of infliximab achieved a PASI 75 (both $P<0.05$ versus placebo). PASI 50 results were not reported. The mean percentage improvement in PASI scores was significantly greater with active therapy than placebo as early as week $2 \quad(P<0.001)$; a dose response was not observed. One patient in each of the low-dose and high-dose infliximab groups withdrew because of adverse events (mild rash and worsening psoriasis, respectively). Headache was more common in the high-dose infliximab group ( 7 of 11 patients) than in the lowdose ( 1 of 11 patients) and placebo (2 of 11 patients) groups. No opportunistic infections were reported. Positive antinuclear antibody titers were detected in 2 patients in the low-dose infliximab group at week 10. Neither patient had any relevant clinical symptoms, and both responded well to infliximab.

\section{Where Do Biologics Fit in the Treatment of Patients With Psoriasis?}

Biologic agents for psoriasis have been proven to offer patients an effective alternative therapy for moderate-to-severe psoriasis. Candidates for biologics may include patients who have exceeded 1 year of cyclosporine therapy, have a history of skin cancer, 
or have an abnormal liver biopsy with methotrexate. Clinical issues that should be taken into consideration include patients who have a concomitant disease (heart failure, TB, sepsis); patients with contraindications to use methotrexate or cyclosporine; and patients who may otherwise be candidates for ultraviolet therapy. Additionally, patient teachability and willingness to be an active participant with injectable therapy may be limiting factors of use. Biologics may hold promise for use in women of childbearing age, although their safety in this patient population has not been determined. In the future, a combination of traditional systemic therapies and biologics may be used to induce faster plaque clearing and longer remissions.

\section{Cost and Cost-Effectiveness of Biologic Agents}

The biologic agents have higher acquisition costs than traditional therapies. However, the current data on the impact of biologic therapies on overall health care costs are limited. Alefacept costs about $\$ 10,000$ for a 12-week cycle. .2 $^{2}$ Patients who respond to alefacept are likely to remain in remission for approximately 7 months and thus would not complete 2 full treatment courses in a year. Other patients may be less responsive to the initial treatment course and, given the drug's potential for incremental efficacy, may opt to receive a second course in the same year. Thus, for 1.5 to 2 courses of alefacept per year, the drug cost would be approximately $\$ 16,667$ to $\$ 20,000$. The estimated cost for a full year of continuous treatment with efalizumab is $\$ 14,000 .^{42}$ The cost per year of therapy with etanercept or infliximab is estimated at $\$ 12,000$, assuming continuous treatment with etanercept and an average of 8 treatments with infliximab. ${ }^{42}$

A literature search revealed 1 publication with cost-efficacy data involving the use of biologic agents for the treatment of psoriasis. ${ }^{43}$ The analysis in this single literature citation was limited for several reasons, as the authors acknowledged. First, there are no comparative data involving any of the biologic agents. Second, the efficacy outcome measure chosen for analysis was a PASI 75 response, which, as mentioned previously, may be too stringent a criterion for assessing the benefits of therapy. Third, the efficacy data used in the analysis were obtained from short-term clinical trials, which may not be reflective of actual practice. Each of the biologic therapies included in the analysis (IV alefacept, etanercept, and infliximab [efalizumab and IM alefacept were not included]) was more costly per treatment success when compared with traditional therapies such as methotrexate, acitretin, cyclosporine, ultraviolet B light, and PUVA. Among the biologic agents, the most cost-effective treatment was infliximab; alefacept and etanercept were comparably more costly per treatment success.

Future models may be able to incorporate head-to-head data with efficacy outcomes that are clinically meaningful (e.g., PASI 50). A model that estimates the cost of achieving symptom-free days and side-effect-free days over the long-term would be beneficial for this chronic disease.

\section{Conclusion}

Psoriasis is an immune-mediated disease that often has a negative impact on the lives of affected patients. Patients with mild, local disease may be treated effectively with topical therapy. Patients with moderate-to-severe disease generally require treatment with systemic therapies or phototherapy, often with adjunctive use of topical therapy. The limitations of traditional therapies and the improved understanding of the immune basis of psoriasis have led to the discovery and use of biologic agents that target the immune defect of psoriasis. These new agents appear to offer clinical benefit for patients who cannot tolerate or are otherwise not candidates for traditional therapies for moderate-to-severe psoriasis. Results of initial clinical trials indicate that these agents provide relatively high response rates while avoiding the collateral organ toxicity and adverse events associated with older treatments.

\section{ACKNOWLEDGMENTS}

The authors would like to acknowledge the invaluable assistance of John F. Aforismo, RPh; Steven R. Feldman, MD, PhD; Kenneth B. Gordon, MD; Richard Langley, MD, FRCPF; and Alan M. Menter, MD, for their time and assistance with the review of the original monograph.

\section{DISCLOSURES}

Funding for an initial concept meeting for this study was provided to SJR Associates, LLC, by Biogen Idec Inc. and obtained by author Sheldon J. Rich. Rich is president of SJR Associates, LLC, and a consultant and speaker for Biogen Idec Inc., Centocor, and Genentech; author Cristina E. Bello-Quintero received a stipend from SJR Associates for attendance at the concept meeting. Rich served as principal author of the study. Study concept and design was contributed by Rich, Bello-Quintero, John F. Aforismo, Steven R. Feldman, Kenneth B. Gordon, Richard Langley, and Alan M. Menter. Analysis and interpretation of data were contributed by Rich. Drafting of the manuscript was the work of Rich and Bello-Quintero, and its critical revision was the work of Rich. Statistical expertise was contributed by Aforismo, Bello-Quintero, Feldman, Gordon, Langley, Mentor, and Rich. Administrative, technical, or material support was provided by Rich.

\section{REFERENCES}

1. Seaton T. Psoriasis. In: Young LY, Koda-Kimbal MA, ed. Applied Therapeutics: The Clinical Use of Drugs. Vancouver, WA: Applied Therapeutics; 1995:37-1-37-7.

2. Peters BP, Weissman FG, Gill MA. Pathophysiology and treatment of psoriasis. Am J Health Syst Pharm. 2000;57:645-62

3. Fleischer AB Jr., Feldman SR, Rapp SR, et al. Disease severity measures in a population of psoriasis patients: the symptoms of psoriasis correlate with selfadministered psoriasis area severity index scores. J Invest Dermatol 1996;107: 26-29.

4. Rapp SR, Feldman SR, Exum ML, Fleischer AB Jr., Reboussin DM. Psoriasis causes as much disability as other major medical diseases. J Am Acad Dermatol. 1999;41:401-07.

5. Rapp SR, Exum ML, Reboussin DM, Feldman SR, Fleischer A, Clark A. The physical, psychological and social impact of psoriasis. J Health Psychol. 1997;2:525-37.

6. Krueger G, Koo J, Lebwohl M, et al. The impact of psoriasis on quality of life: results of a 1998 national psoriasis foundation patient-membership survey. Arch Dermatol. 2001;137:280-84. 
7. Singri P, West DP, Gordon KB. Biologic therapy for psoriasis: the new therapeutic frontier. Arch Dermatol. 2002;138:657-63.

8. Ellis CN, Krueger GG, for the Alefacept Clinical Study Group. Treatment of chronic plaque psoriasis by selective targeting of memory effector $\mathrm{T}$ lymphocytes. N Engl J Med. 2001;345:248-55.

9. Lebwohl M. Psoriasis. Lancet. 2003;361:1197-204.

10. Patel NM, Elias SS, Cheigh NH. Acne and psoriasis. In: Dipiro JT, Talbert RL, Yee GC, Matzke GR, Wells BG, Posey LM, ed. Pharmacotherapy: A Pathophysiologic Approach. New York, NY: McGraw-Hill/Appleton \& Lange; 2002:1689-1704

11. Finlay AY, Salek MS, Haney J, for the Alefacept Clinical Study Group. Intramuscular alefacept improves health-related quality of life in patients with chronic plaque psoriasis. Dermatology. 2003;206:307-15.

12. Feldman SR, Menter A, Koo JY. Improved health-related quality of life following a randomized controlled trial of alefacept treatment in patients with chronic plaque psoriasis. Br J Dermatol. 2004;150:317-26.

13. Lebwohl M, Ali S. Treatment of psoriasis. Part 1. Topical therapy and phototherapy. J Am Acad Dermatol. 2001;45:487-98.

14. Krueger GG, Papp KA, Stough DB, Loven KH, Gulliver WP, Ellis CN, for the Alefacept Clinical Study Group. A randomized, double-blind, placebocontrolled phase III study evaluating efficacy and tolerability of 2 courses of alefacept in patients with chronic plaque psoriasis. J Am Acad Dermatol. 2002;47:821-33.

15. Gordon KB, Langley RG. Remittive effects of intramuscular alefacept in psoriasis. J Drugs Dermatol. 2003;2:624-28.

16. National Psoriasis Foundation. Facts: Psoriasis. Available at: http://www.psoriasis.org/facts/psoriasis/. Accessed January 14, 2004.

17. Yamauchi PS, Rizk D, Kormeili T, Patnaik R, Lowe NJ. Current systemic therapies for psoriasis: Where are we now? J Am Acad Dermatol. 2003;49 (suppl):S66-S77.

18. Zanolli M. Phototherapy treatment of psoriasis today. J Am Acad Dermatol. 2003;49(suppl):S78-S86.

19. Lebwohl M, Ali S. Treatment of psoriasis. Part 2. Systemic therapies. J Am Acad Dermatol. 2001;45:649-61.

20. Ashcroft DM, Po ALW, Griffiths CEM. Therapeutic strategies for psoriasis. J Clin Pharm Ther. 2000;25:1-10.

21. Koo J, Lebwohl M. Duration of remission of psoriasis therapies. J Am Acad Dermatol. 1999;41:51-59.

22. Lebwohl M, Christophers E, Langley R, Ortonne JP, Roberts J, Griffiths CEM, for the Alefacept Clinical Study Group. An international, randomized, double-blind, placebo-controlled phase 3 trial of intramuscular alefacept in patients with chronic plaque psoriasis. Arch Dermatol. 2003;139:719-27.

23. Callis KP, Chahda A, Vaishnaw A, Krueger GG. Reduction of CD45RO ${ }^{+}$ effector T lymphocytes is not observed in the treatment of psoriasis with methotrexate [abstract]. J Invest Dermatol. 2002;119:244.

24. Krueger GG. Selective targeting of T-cell subsets: focus on alefacepta remittive therapy for psoriasis. Expert Opin Biol Ther. 2002;2:431-41.

25. Amevive (alefacept) prescribing information. Available at:

http://amevive.com/amv/index_amevive2.jsp. Accessed January 14, 2004.

26. Gordon KB, Vaishnaw AK, O'Gorman J, Haney J, Menter A, for the Alefacept Clinical Study Group. Treatment of psoriasis with alefacept. Correlation of clinical improvement with reductions of memory T-cell counts. Arch Dermatol. 2003;139:1563-70.
27. Ortonne J-P, Lebwohl M, Griffiths CEM, for the Alefacept Clinical Study Group. Alefacept-induced decreases in circulating blood lymphocyte counts correlate with clinical response in patients with chronic plaque psoriasis. Eur J Dermatol. 2003;13:117-23.

28. Gottlieb AB, Casale TB, Frankel E et al. CD4 ${ }^{+}$T-cell-directed antibody responses are maintained in patients with psoriasis receiving alefacept: Results of a randomized study. J Am Acad Dermatol. 2003;49:816-25.

29. Lowe NJ, Gonzalez J, Bagel J, Caro I, Ellis CN, Menter A. Repeat courses of intravenous alefacept in patients with chronic plaque psoriasis provide consistent safety and efficacy. Int J Dermatol. 2003;42:224-30.

30. Ellis CN, Mordin MM, Adler EY. Effects of alefacept on health-related quality of life in patients with psoriasis: results from a randomized, placebocontrolled phase II trial. Am J Clin Dermatol. 2003;4:131-39.

31. Cather JC, Cather JC, Menter A. Modulating T-cell responses for the treatment of psoriasis: a focus on efalizumab. Expert Opin Biol Ther. 2003;3:361-70.

32. Raptiva (efalizumab) prescribing information. Available at: http://www.raptiva.com/index.jsp. Accessed April 20, 2004.

33. Gordon KB, Papp KA, Hamilton TK, et al, for the Efalizumab Study Group. Efalizumab for patients with moderate to severe plaque psoriasis. A randomized controlled trial. JAMA. 2003;290:3073-80.

34. Lebwohl M, Tyring SK, Hamilton TK, et al, for the Efalizumab Study Group. A novel targeted T-cell modulator, efalizumab, for plaque psoriasis. N Engl J Med. 2003;349:2004-13.

35. Enbrel (etanercept) prescribing information. Available at http://www.enbrel.com/index.jsp. Accessed April 20, 2004.

36. American College of Rheumatology. FDA meeting March 2003: update on the safety of new drugs for rheumatoid arthritis. Part II: CHF, infection and other safety issues. Available at http://www.rheumatology.org/publications/hotline/0803chf.asp?aud=mem. Accessed April 20, 2004.

37. Mease PJ, Goffe BS, Metz J, VanderStoep A, Finck B, Burge DJ. Etanercept in the treatment of psoriatic arthritis and psoriasis: a randomised trial. Lancet. 2000;356:385-90.

38. Gottlieb AB, Matheson RT, Lowe N, et al. A randomized trial of etanercept as monotherapy for psoriasis. Arch Dermatol. 2003;139:1627-32.

39. Leonardi CL, Powers JL, Matheson RT et al, for the Etanercept Psoriasis Study Group. Etanercept as monotherapy in patients with psoriasis. N Engl J Med. 2003;349;2014-22.

40. Remicade (infliximab) prescribing information. Available at: http://www.remicade.com/. Accessed April 20, 2004

41. Chaudhari U, Romano P, Mulcahy LD, Dooley LT, Baker DG, Gottlieb AB. Efficacy and safety of infliximab monotherapy for plaque-type psoriasis: a randomised trial. Lancet. 2001;357:1842-47.

42. National Psoriasis Foundation. Treatment: Biologics. What are biologics? Available at: http://www.psoriasis.org/treatment/psoriasis/biologics.php. Accessed April 20, 2004.

43. Feldman SR, Garton R, Averett W, Balkrishnan R, Vallee J. Strategy to manage the treatment of severe psoriasis: considerations of efficacy, safety and cost. Expert Opin Pharmacother. 2003;4:1525-33. 